\title{
Usage of Learning Management System (Moodle) among Postgraduate Students: UTAUT Model
}

\author{
Arumugam Raman ${ }^{1}$, Yahya Don ${ }^{1}$, Rozalina Khalid ${ }^{1}$ \& Mohd Rizuan ${ }^{1}$ \\ ${ }^{1}$ University Utara Malaysia, Malaysia \\ Correspondence: Arumugam Raman, University Utara Malaysia, Malaysia. E-mail: arumugam@uum.edu.my
}

Received: April 16, 2014 Accepted: May 22, 2014 Online Published: June 24, 2014

doi:10.5539/ass.v10n14p186 URL: http://dx.doi.org/10.5539/ass.v10n14p186

\begin{abstract}
The application of a learning management system (LMS) Moodle is learning and teaching platform in Universiti Utara Malaysia. To examine the level of acceptance of this technology, the UTAUT (Unified theory of acceptance and use of technology) Model is used to infer individual students' technology acceptance by explaining the variants in Behavior Intention (BI). This study is conducted on 65 postgraduate students pursuing their study at UUM. The students are all studying the same course and they are exposed to the application of LMS known as 'Moodle UUM Learning Zone'. A set of questionnaire, in the UTAUT Model which is developed by Venkatesh et al. (2003), is used to collect data which is then descriptively analyzed by using IBM SPSS Statistics Version 20 and SmartPLS 2.0. The findings of the study found that Performance Expectancy (PE) $(\beta=0.418, p<0.01)$, Social Influence $(\mathrm{SI})(\beta=0.238, \mathrm{p}<0.01)$ and Facilitating Conditions $(\mathrm{FC})(\beta=0.120, \mathrm{p}<0.01)$ have positive influence towards 'Behavioral Intention' (BI). The value $\mathrm{R}^{2}=0.520$ showed that $52.0 \%$ of the variants in the application of Learning zone can be explained by Behavioral Intention (BI). Consequently, the result related to moderator influence in terms of gender showed that all the four UTAUT Model constructs failed to reject HO5. The results also showed that moderator influence in terms of gender with PE, EE, SI and FC does not have significant positive influence towards BI. The findings of this study which are hoped to help encourage instructors and students to use this technology in their learning and teaching processes, have proven that LMS 'Moodle' is beneficial and effective for learning and teaching processes.
\end{abstract}

Keywords: learning management system (LMS), learning zone, unified theory of acceptance and use of technology (UTAUT), performance expectancy (PE), effort expectancy (EE), social influence (SI), facilitating conditions (FC), gender

\section{Introduction}

At present majority of the higher institutions such as universities and colleges offer e-learning courses. In these higher institutions of learning, there are still courses that need to be disseminated in a traditional manner, but some are conducted fully online. E-learning needs an environment where everything, from managing to implementing, has to done online through the use of the internet. In many cases, this task is completed by using LMS. LMS provides all sorts of support for instructors to create manage the courses and interact online. The learning and teaching interaction in the Open Source Software (OSS) makes a community more active and developed. Cheung (2006) conducted a study to compare the usage of online learning system such as WebCT, Blackboard and OSS Moodle, and found that commercial software are better in terms of technical support. A high impact evaluation on OSS support showed that Moodle is the best choice for teaching and learning online due to its support system. The quality in external achievement of OSS in terms of service preparation for higher education learning is vital as the additional usage of OSS. Good quality in external achievement in terms of service preparation in OSS is also important to international educators (Hedgebeth, 2007). 


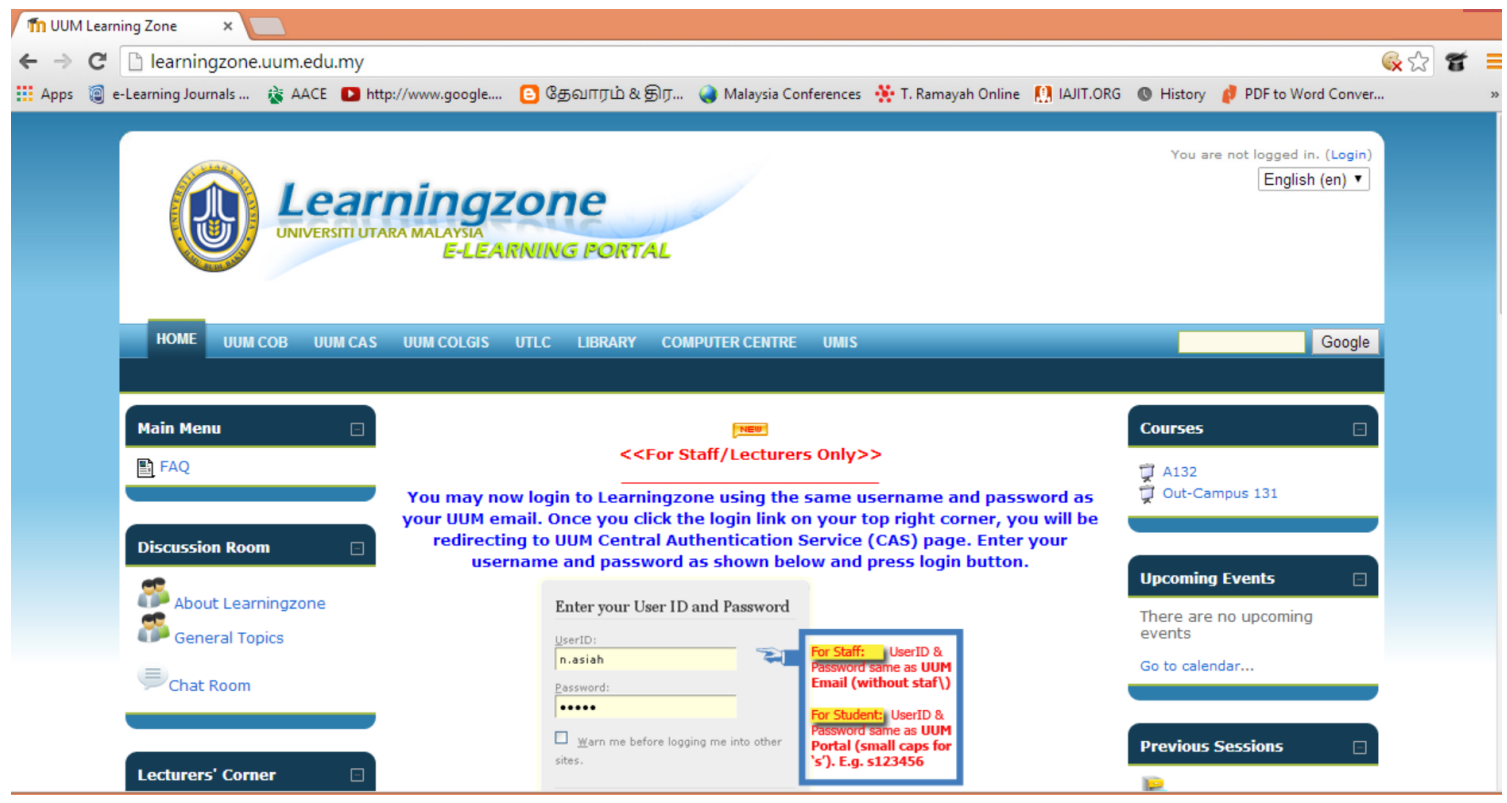

Figure 1. Universiti Utara Malaysia's e-learning portal

\section{Literature Review}

UTAUT Model is technology acceptance model which was developed by Venkatesh et al. This model was developed to describe the acceptance of a technology among users. This model describes four main constructs namely; 1) Performance Acceptance which is defined as how far a user believes that using the system can help him or her to achieve a skill in his or her work performance (Venkatesh, Morris, Davis, \& Davis, 2003); 2) Effort Expectancy means the level of ease which is related to the use of the system (Venkatesh et al., 2003); 3) Social Influence which is classified by UTAUT is how far a user believes that a person who is more important than him or her thinks that he or she should use the technology (Venkatesh et al., 2003); and 4) Facility Conditions that refer to how far the technology ease the organization and how a user believes that the organization and technical infrastructure that exist can support the use of the technology (Venkatesh et al., 2003). The first until the third constructs are the direct determiner for BI and the fourth direct determiner is UB that measures the possibility of an individual to use the technology (Venkatesh et al., 2003). The role of gender which has a strong and permanent basic psychology (Venkatesh et al., 2003), age, experience and the voluntary use are claimed to decrease the effect of the four main constructs towards BI. This model has been developed though the study and integration of eight other developed research models which have been used such as The Theory of Reasoned Action (TRA), Technology Acceptance Model (TAM), Motivational Model (MM), Theory of Planned Behavior (TPB), Model Combining the Technology Acceptance Model and Theory of Planned Behavior (C-TAM-TPB), Model of PC Utilization (MPCU), Innovation Diffusion Theory (IDT), and Social Cognitive Theory (SCT).

The research 'Assessing User Acceptance toward Blog Technology Using the UTAUT Model' which was conducted by Pardamean and Susanto (2012) found that the e-learning media interactive function is able to attract the students' interest and attention. They have agreed that e-learning media is also suitable for collaboration and shared knowledge. This explains that social factors and environment or Social Influence (SI) is a strong booster for students to use blogs in their e-commerce learning and teaching. In the research 'Interactive Whiteboard Acceptance: Applicability of the UTAUT Model to Student Teachers' by Wong et al. (2013), found that teachers get involved in the 'Smart Board' technology when they see the value and benefits. This shows that the policy makers and curriculum designers have to spell out the advantages of using the technology and organize training sessions on how to use it effectively. The high level of Effort Expectance (EE) will result in high Behavioral Intention (BI) among teachers to use the 'Smart Board' technology. According to El-Gayar et al. (2011), in their study 'Student's Acceptance of Tablet PCs and Implications for Educational Institutional Technology \& Society', the main determiner towards the acceptance of PC's Tablet is the students' attitude, which is followed by Performance Expectancy, (PE), Facilitating Conditions (FC), Effort Expectancy (EE) and Social Influence (SI). A study by Oye et al. (2011) titled 'A Model of ICT Acceptance and Use for Teachers in 
Higher Education Institutions' found that among the four constructs in UTAUT, 'Performance Expectancy' (PE) is the most influential factor towards the acceptance and usage of ICT among teachers. 78\% of the respondents believed that ICT use in their work will increase their opportunity for promotion. They also claimed that monetary incentive reward is related to the use of ICT. Future prospect to get a better job with a better pay is also based on the use of ICT.

\subsection{Hypotheses}

Research Hypotheses:

$\mathrm{HO}_{1}$ : Performance expectancy (PE) has a positive effect towards Behavioral Intention (BI).

$\mathrm{HO}_{2}$ : Effort expectancy (EE) has a positive effect towards Behavioral Intention (BI).

$\mathrm{HO}_{3}$ : Social influences (SI) have a positive effect towards Behavioral Intention (BI).

$\mathrm{HO}_{4}$ : Facility conditions (FC) have a positive effect towards Behavioral Intention (BI).

$\mathrm{HO}_{5}$ : Gender moderates the relationship between PE and BI.

$\mathrm{HO}_{6}$ : Gender moderates the relationship between EE and BI.

$\mathrm{HO}_{7}$ : Gender moderates the relationship between SI and BI.

$\mathrm{HO}_{8}$ : Gender moderates the relationship between FC and BI.

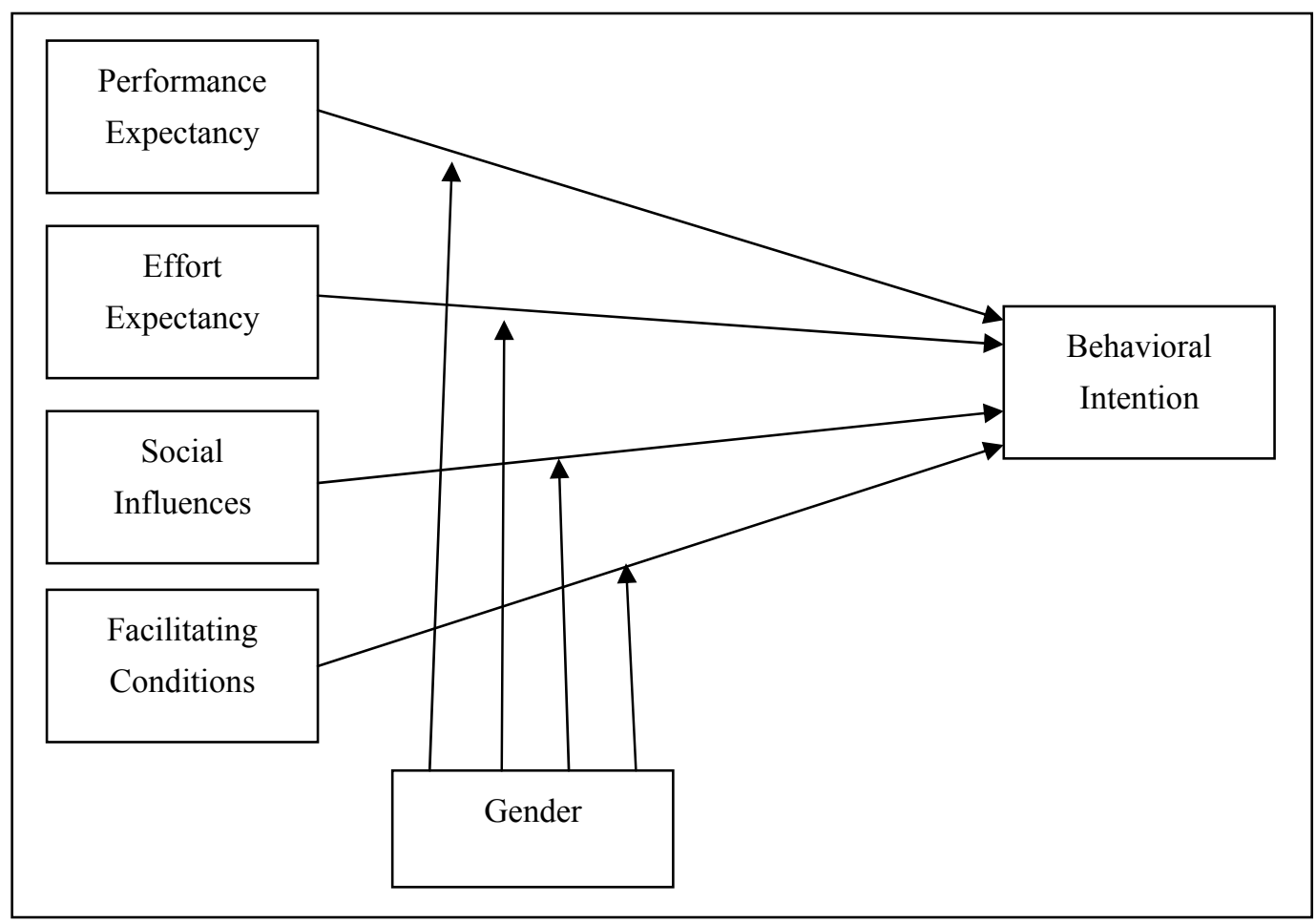

Figure 1. Conceptual framework of study

\section{Methodology}

This study is quantitative in nature by using 30-item questionnaire, developed by Venkatesh et al. (2003), which consists of Liker 1-5 scale from totally disagree (1) to totally agree (5). This questionnaire was translated, validated and distributed to all the participants involved in this study. The sampling for this study consists of 65 students pursuing their M.Ed. (ELT) in mixed-mode and coursework mode at UUM. These students are exposed to the use of Learning Management System (LMS) known as 'Moodle UUM Learning Zone' which is used in the teaching and learning to evaluate the level of acceptance and use of this system with the use of the UTAUT Model. Each participant is given the questionnaire right after they have been exposed to LMS teaching and learning in their course session. The data is then analyzed using IBM SPSS Statistics Version 20 and SmartPLS 2.0 . 


\section{Findings}

Table 1 shows the number of respondents involved of which 27 are male (41.5\%) and 38 are female (58.5\%).

This shows that the number of respondents differ by 11(16.9\%) between the two genders.

Table 1. Gender of respondents

\begin{tabular}{lll}
\hline Gender & Frequency & Percentage (\%) \\
\hline Male & 27 & 41.5 \\
Female & 38 & 58.5 \\
Total & 65 & 100 \\
\hline
\end{tabular}

According to Hair et al. (2010), the level of reliability of an instrument is shown when the responses are consistent. Table 2 shows the reliability of each construct. UTUT Model is reflective in nature and Hair et al. (2011) posits that composite reliability (CR) must exceed 0.7 , reliability of items (loadings) must exceed 0.70 , convergent validity (AVE) must exceed 0.50 and the square root of discriminant validity AVE for each construct must be higher compared to the correlation with other constructs (Fornell-Larcker, 1981).

Table 2. Cronbach alpha value $\alpha$

\begin{tabular}{ll}
\hline Construct & Cranach Alpha $\boldsymbol{\alpha}$ \\
\hline Performance Expectancy (PE) & 0.88 \\
Effort Expectancy (EE) & 0.91 \\
Social Influence (SI) & 0.77 \\
Facilitating Conditions (FC) & 0.84 \\
Behavioral Intention (BI) & 0.97 \\
\hline
\end{tabular}

\subsection{Convergent Validity}

Average Variants Extracted (AVE) is used as general measurement to determine convergent validity for each construct. The AVE value, 0.5 or higher shows that each item completes a part of the item variant. However, an AVE less than 0.5 indicate that, on average, more error remains in the items than the variants explained by the construct.

Table 3. Convergent validity

\begin{tabular}{|c|c|c|c|c|}
\hline Construct & & Loadings & $A V E$ & $C R$ \\
\hline \multirow[t]{6}{*}{ Performance Expectancy PE) } & PE1 & 0.87 & 0.62 & 0.91 \\
\hline & PE2 & 0.76 & & \\
\hline & PE3 & 0.89 & & \\
\hline & PE4 & 0.81 & & \\
\hline & PE5 & 0.64 & & \\
\hline & PE6 & 0.73 & & \\
\hline \multirow[t]{6}{*}{ Effort Expectancy (EE) } & EE1 & 0.78 & 0.69 & 0.93 \\
\hline & EE2 & 0.83 & & \\
\hline & EE3 & 0.89 & & \\
\hline & EE4 & 0.87 & & \\
\hline & EE5 & 0.78 & & \\
\hline & EE6 & 0.83 & & \\
\hline \multirow[t]{4}{*}{ Social Influence (SI) } & SI1 & 0.71 & 0.59 & 0.85 \\
\hline & $\mathrm{SI} 2$ & 0.74 & & \\
\hline & SI3 & 0.86 & & \\
\hline & SI4 & 0.74 & & \\
\hline \multirow[t]{3}{*}{ Facilitating Conditions (FC) } & $\mathrm{FC} 1$ & 0.76 & 0.54 & 0.87 \\
\hline & $\mathrm{FC} 2$ & 0.82 & & \\
\hline & $\mathrm{FC} 4$ & 0.63 & & \\
\hline
\end{tabular}




\begin{tabular}{lllll}
\hline Construct & & Loadings & AVE & $C R$ \\
\hline & FC5 & 0.76 & & \\
& FC6 & 0.77 & & \\
Behavioral Intention (BI) & FC7 & 0.66 & 0.95 & 0.98 \\
& BI5 & 0.98 & & \\
\hline
\end{tabular}

From Table 3, it shows that loading value (items) exceeds 0.7 except PE5 and FC4, but FC4 is retained because its omission does not increase AVE. However, item FC3 is omitted because the loading is very low (0.037). Convergent validity exists because AVE for every construct exceeds 0.50 .

Table 4. Construct correlation matrix

\begin{tabular}{|c|c|c|c|c|c|}
\hline & $\begin{array}{l}\text { Behavioral } \\
\text { Intention (BI) }\end{array}$ & $\begin{array}{l}\text { Effort } \\
\text { Expectancy (EE) }\end{array}$ & $\begin{array}{l}\text { Facilitating } \\
\text { Conditions (FC) }\end{array}$ & $\begin{array}{l}\text { Performance } \\
\text { Expectancy (PE) }\end{array}$ & $\begin{array}{l}\text { Social } \\
\text { Influence (SI) }\end{array}$ \\
\hline $\begin{array}{l}\text { Behavioral Intention } \\
\text { (BI) }\end{array}$ & 0.973 & & & & \\
\hline $\begin{array}{l}\text { Effort Expectancy } \\
\text { (EE) }\end{array}$ & 0.589 & 0.830 & & & \\
\hline $\begin{array}{l}\text { Facilitating } \\
\text { Conditions (FC) }\end{array}$ & 0.569 & 0.695 & 0.734 & & \\
\hline $\begin{array}{l}\text { Performance } \\
\text { Expectancy (PE) }\end{array}$ & 0.679 & 0.795 & 0.657 & 0.789 & \\
\hline Social Influence (SI) & 0.588 & 0.529 & 0.595 & 0.607 & 0.765 \\
\hline
\end{tabular}

\subsection{Discriminant Validity}

According to Fornell and Larcker (1981), when the average square root of extracted variants exceeds the correlation value between all the variables, then discriminant validity exists (Table 4). From Table 4, it can be summarized that there exists discriminant validity where $\mathrm{BI}, \mathrm{AVE}^{2}$ (BOLD) is greater than correlation indicator in $\mathrm{EE}, \mathrm{FC}, \mathrm{PE}$ and ST. However, in indicator for $\mathrm{EE}$, the $\mathrm{AVE}^{2}$ is greater than the correlation indicator in $\mathrm{FC}$, $\mathrm{PE}$ and SI.

Nevertheless, in the indicator for FC, the $\mathrm{AVE}^{2}$ (BOLD) is lower than the correlation in the indicator for PE and SI. Consequently, in the indicator for PE, the $\mathrm{AVE}^{2}$ (BOLD) has become higher again from the correlation in the indicator for SI.

Based on Table 5, it shows that path coefficient $\left(\mathrm{R}^{2}\right)$ for each construct (latent variable) that shows difference in the level of correlation can be explained. The result shows Performance Expectancy $(\mathrm{PE})(\beta=0.418, \mathrm{p}<0.01)$, Social Influence $(\mathrm{SI})(\beta=0.238, \mathrm{p}<0.01)$ and Facilitating Conditions $(\mathrm{FC})(\beta=0.120, \mathrm{p}<0.01)$ have positive influence towards Behavioral Intention (BI). Therefore, $\mathrm{HO}_{1}, \mathrm{HO}_{3}$ and $\mathrm{HO}_{4}$ are accepted, because the value $\mathrm{R}^{2}=0.52$ shows $52.0 \%$ from the variants in LMS 'Moodle' through 'UUM Learning Zone', by the respondents. However, $\mathrm{EE}(\beta=0.048, \mathrm{p}>0.01)$ has no positive effect on $\mathrm{BI}$. Therefore, $\mathrm{HO}_{2}$ is rejected in the use of LMS 'Moodle" through 'UUM Learning Zone', by the respondents. The findings show that PE, SI and FC have significant relationship with BI.

Table 5. Path coefficient and hypotheses results

\begin{tabular}{|c|c|c|c|c|}
\hline Hypotheses & Relationship & Coefficient ( $\beta$ ) & t value & Result \\
\hline $\mathrm{HO}_{1}$ & $\mathrm{PE} \rightarrow \mathrm{BI}$ & 0.418 & 2.516 & Accepted \\
\hline $\mathrm{HO}_{2}$ & $\mathrm{EE} \rightarrow \mathrm{BI}$ & 0.048 & 0.213 & Rejected \\
\hline $\mathrm{HO}_{3}$ & $\mathrm{SI} \rightarrow \mathrm{BI}$ & 0.238 & 3.089 & Accepted \\
\hline $\mathrm{HO}_{4}$ & $\mathrm{FC} \rightarrow \mathrm{BI}$ & 0.120 & 1.152 & Accepted \\
\hline
\end{tabular}




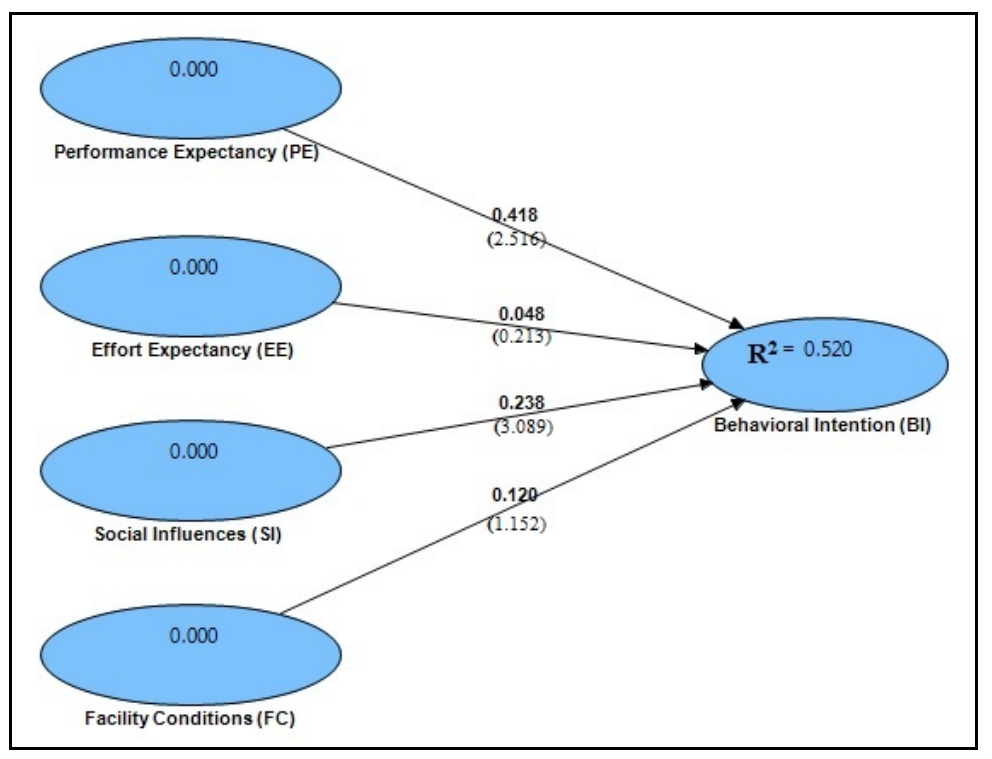

Figure 2. Result of path analysis

Table 6. Test on gender influence on suggested model

\begin{tabular}{llllll}
\hline Construct & Gender & Weight (min) & Error & $\boldsymbol{t}$ & $\boldsymbol{p}$ \\
\hline PE & Female & 0.374 & 0.145 & 0.649 & 0.518 \\
& Male & 0.243 & 0.130 & & \\
EE & Female & -0.108 & 0.311 & 0.562 & 0.576 \\
& Male & 0.105 & 0.128 & & \\
SI & Female & 0.328 & 0.083 & 0.020 & 0.980 \\
& Male & 0.326 & 0.092 & & \\
FC & Female & 0.284 & 0.150 & 0.646 & 0.521 \\
& Male & 0.165 & 0.064 & & \\
\hline
\end{tabular}

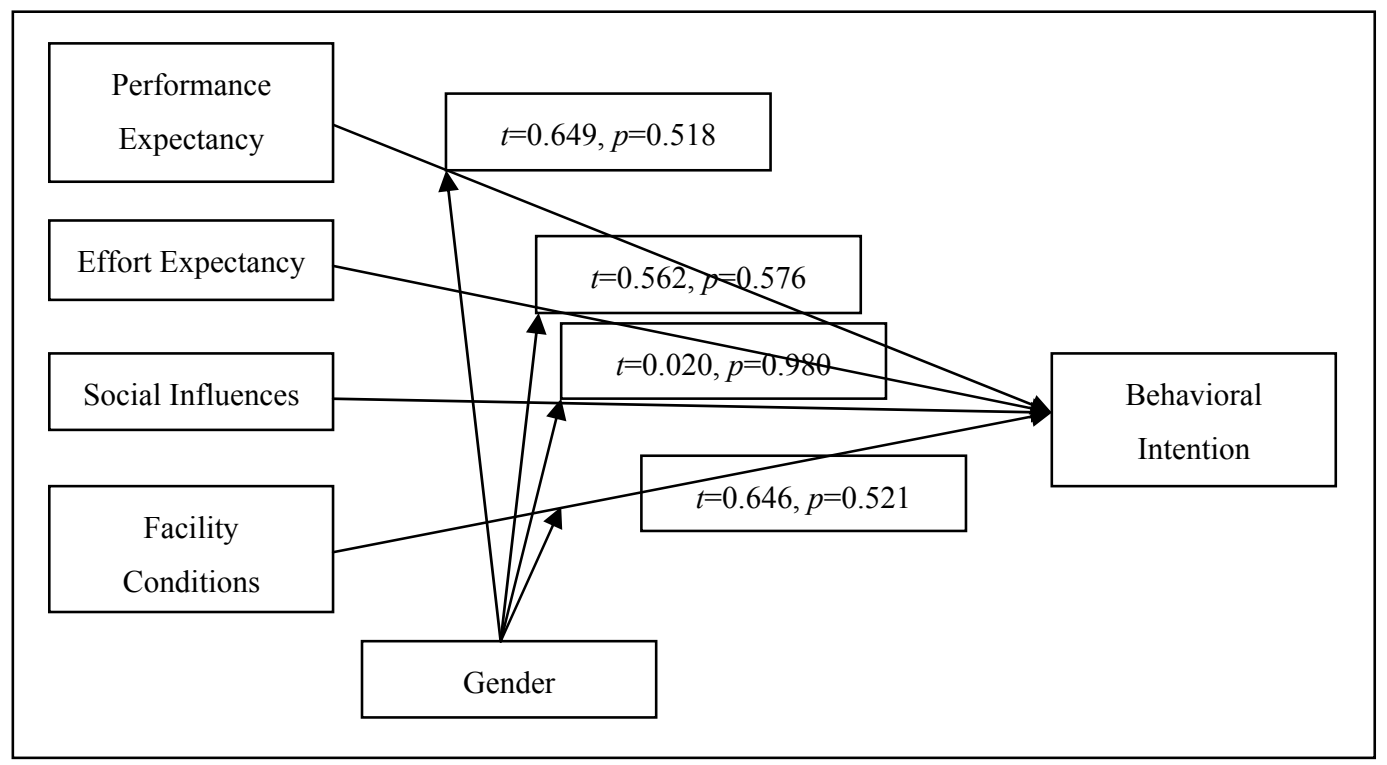

Figure 3. Analysis of gender as moderator on suggested model

The analysis shows that gender is not significant where $\mathrm{p}>0.05$ for every test. 


\section{Conclusion}

The findings of this study are parallel with the findings in the study done by Pardamean \& Susanto (2012) who found that the media interactive function of e-learning can attract the interest and attention of the students. They also agreed that e-learning media is suitable for collaboration and sharing of knowledge. This clearly shows that social and environment factors or SI is the booster for students to use blog in their e-commerce learning. To hasten the implementation of blog in e-commerce learning, encouragement and support from peers is vital. The findings in this study are similar with El-Gayar et al. (2011) where they found that the main determiner of Tablet PCs acceptance among students is the students' attitude followed by PE, FC, EE and SI but the result of this study is dissimilar in terms of gender influence in The UTAUT Model which can be seen in the study by Alfonso et al. (2012). Their study aimed at testing the gender effect with a sample of 2,175 users of Electronic Document Management System (EDMS) at the Portuguese City Council. The result showed that gender when related to PE with BI proved to have a strong relationship among male than female. However, further research needs to be done with regards to time allotted for the students and also computer skills among the students to get a better picture of the acceptance of LMS among Masters Students in UUM.

\section{References}

Afonso, C. M., Roldán, J. L., Sánchez-Franco, M., \& de la Gonzalez, M. O. (2012). The moderator role of Gender in the Unified Theory of Acceptance and Use of Technology (UTAUT): A study on users of Electronic Document Management Systems. Presented at the 7th International Conference on Partial Least Squares and Related Methods. Houston, Texas, USA.

El-Gayar, O. F., Moran, M., \& Hawkes, M. (2011). Student's acceptance of tables PCs and implications for educational instructions. Educational Technology \& Society, 14(2), 58-70.

Fornell, C., \& Larcker, D. F. (1981). Evaluating structural equation models with unobservable variables and measurement error. Journal of Marketing Research, 48, 39-50. http://dx.doi.org/10.2307/3151312

Hair, J. F., Black, W. C., Babin, B. J., \& Anderson, R. E. (2010). Multivariate Data Analysis (7th ed.). Upper Saddle River, New Jersey: Prentice Hall.

Hair, J. F., Ringle, C. M., \& Sarstedt, M. (2011). PLS-SEM: Indeed a silver bullet. The Journal of Marketing Theory and Practice, 19(2), 139-152. http://dx.doi.org/10.2753/MTP1069-6679190202

Hedgebeth, D. (2007). Gaining competitive advantage in a knowledge-based economy through the utilization of open source software'. The journal of information and knowledge management systems, 37(3), 284-294.

Oye, N. D., Iahad, N. A., \& Rabin, Z. A. (2011). A model of ICT acceptance and use for teachers in higher education institutions. International Journal of Computer Science \& Communication Networks, 1(1), 21-40.

Pardamean, B., \& Susanto, M. (2012). Assessing user acceptance toward blog technology using the UTAUT model. International Journal of Mathematics and Computers in Simulation, 1(6), 203-212.

Venkatesh, V., \& Zhang, X. (2010). Unified theory of acceptance and use of technology: U.S. vs. China. Journal of Global Information Technology Management, 13, (1), 5-27.

Venkatesh, V., Morris, M. G., Davis, G. B., \& Davis, F. D. (2003). User acceptance of information technology: Toward a unified view. MIS Quarterly, 27(3), 425-478.

Venkatesh, V., Morris, M. G., Davis, G. B., Davis, F. D., DeLone, W., McLean, E., ... Chin, W. (2003). User acceptance of information technology: Toward a unified view. INFORM MANAGEMENT, 27, 425-478.

Wong, K. T., Teo, T., \& Russo, S. (2013). Interactive whiteboard acceptance: Applicability of the UTAUT model to student teachers. Asia Pacific Edu Res, 22(1), 1-10. http://dx.doi.org/10.1007/s40299-012-0001-9

\section{Copyrights}

Copyright for this article is retained by the author(s), with first publication rights granted to the journal.

This is an open-access article distributed under the terms and conditions of the Creative Commons Attribution license (http://creativecommons.org/licenses/by/3.0/). 